\title{
Pensasmustikka pohjoisessa vain harrastuskasvi
}

Kalle Hoppula $^{1)}$, Kati Hoppula ${ }^{1)}$, Risto Tahvonen ${ }^{2)}$, Vesa Järvelin ${ }^{1)}$, Janne Ylijoki ${ }^{1)}$, Kaisa Soppela ${ }^{3)}$, Sirkka Luoma ${ }^{4}$, Hanna Kekkonen ${ }^{4}$

${ }^{1)}$ MTT Sotkamo, Kipinäntie 16, 88600 Sotkamo,etunimi.sukunimi@mtt.fi

${ }^{2)}$ MTT Piikkiö,Toivonlinnantie 518,21500 Piikkiö, etunimi.sukunimi@mtt.fi

${ }^{3)}$ MTT Rovaniemi, Eteläranta 55, 96300 Rovaniemi, etunimi.sukunimi@mtt.fi

${ }^{4)}$ MTT Ruukki, Tutkimusasemantie 15,92400Ruukki, etunimi.sukunimi@mtt.fi

\section{Tiivistelmä}

MTT testasi pensasmustikkalajikkeiden Aino, Alvar, Arto, Hele, Jorma, North Blue, Patriot, Saani, Sine, Siro ja Tumma menestymistä Sotkamossa (Kainuu), Ruukissa (Pohjois-Pohjanmaa) ja Rovaniemellä (Lappi) vuosina 2008-2011. Kokeiden tavoitteena oli hakea menestymisen pohjoisrajoja lajikkeittain ja tarkentaa lajikkeiden viljelysuosituksia. Kokeet olivat osa Marjanviljelystä vahva elinkeino Pohjois-Suomeen -hanketta, jota rahoitettiin Euroopan maaseuturahastosta Kainuun, Lapin ja Pohjois-Pohjanmaan Ely-keskusten kautta.

Mikään testatuista lajikkeista ei pystynyt tuottamaan Rovaniemellä satoa ja yhtään testatuista pensasmustikkalajikkeista ei voida suositella Lappiin. Sen sijaan Ruukissa ja Sotkamossa satoa poimittiin kaikista lajikkeista, tosin heikoimmin menestyneillä lajikkeilla satotasot jäivät erittäin pieniksi. Mikään lajike ei yltänyt Etelä-Suomen satotasoihin. Parhaimmillaan satotasot olivat kokeissa 300-400 g/taimi eli 1500-2000 kg/ha, kun Etelä-Suomessa saadaan vuodessa satoa yleisesti 1-2 $\mathrm{kg} /$ pensas eli $5000-10000 \mathrm{~kg} / \mathrm{ha}$. Nykyisillä viljelyn tuotantokustannuksilla ja tuottajahinnoilla näissä kokeissa saadut satotasot eivät todennäköisesti riitä kannattavaan kaupalliseen viljelyyn.

Kokeissa parhaiten menestyneitä lajikkeita voi kuitenkin käyttää kotipuutarhalajikkeina EteläKainuussa ja eteläisellä Pohjois-Pohjanmaalla, jos hyväksyy alhaiset satotasot ja toistuvat talvivauriot. Tällaisia, edellä mainitulla alueella harrastajakäyttöön sopivia lajikkeita ovat ainakin Aino, Alvar, Jorma, Sine, Siro ja North Blue. Kaikkein talvenkestävimpiä näistä vaikuttaisivat olevan Aino ja Sine. Sadontuoton ja talvehtimisen kannalta heikoimpia lajikkeita Arto ja Patriot ei voida suositella Kainuuseen eikä Pohjois-Pohjanmaalle. Lajikkeista Saani, Hele ja Tumma ei vielä pystytä tämän koeaineiston perusteella antamaan luotettavia viljelysuosituksia.

Talvivaurioista huolimatta pensasmustikka kykeni sadontuottoon Kainuun ja PohjoisPohjanmaan eteläosissa. Etelä-Lapissa talvivauriot olivat liian voimakkaita ja kasvukausi oletettavasti liian lyhyt pensasmustikoiden menestymistä ajatellen. 


\title{
Johdanto
}

Pensasmustikan viljelypinta-ala on Suomessa noin 100 ha tasoa ja viljely on ilmastollisista syistä keskittynyt Etelä- ja Väli-Suomeen alueille, joilla talvet ovat riittävän leutoja ja lämpösumma on yleensä riittävä pensasmustikan kypsymiselle ja tuleentumiselle. Ensimmäiset pensasmustikat tuotiin Suomeen 1947, jolloin lajiketestaus Suomessa aloitettiin.

Lajikejalostus aloitettiin Suomessa 1960-luvun alussa ja sen myötä on syntynyt useita lajikkeita: Aron, Arne, Arto, Aino, Alvar, Sine, Siro, Tumma, Hele, Jorma ja Saani. Näistä vuonna 2011 valiotaimituotannossa olivat Sine, Aino, Alvar, Arto, Jorma ja Saani. Lisäksi Suomessa on ollut myynnissä joitakin amerikkalaisia lajikkeita, joista valiotaimituotannossa 2011 oli vain North Blue. Valiotaimituotantoon on valikoitu lajikkeet, jotka soveltuvat parhaiten kaupalliseen viljelyyn.

Kotimaisessa lajikejalostuksessa on panostettu erityisesti talvenkestävyyteen muun muassa risteyttämällä amerikkalaisten lajikkeiden kanssa kotimaista juolukkaa. Tällä tavoin alun perin vain Ivyöhykkeen parhailla kasvupaikoilla hengissä selviävästä lajista on pystytty jalostamaan kasvi, jonka viljelysuositus ylettyy parhailla lajikkeilla IV-vyöhykkeelle saakka. Valiotaimituotannosta olevista lajeista IV-vyöhykkeelle yltävät Sine, Aino, Alvar ja Saani, III-vyöhykkeelle Arto ja North Blue sekä I-vyöhykkeelle Jorma. Lisäksi Suomessa on myynnissä muutamia muita lajikkeita, muun muassa vanhempia suomalaisia lajikkeita (esimerkiksi Tumma, Hele ja Siro) ja amerikkalaisia lajikkeita (esimerkiksi Patriot).

Halusimme testata pensasmustikkalajikkeiden viljelymahdollisuuksia nykyisten suositusvyöhykkeiden pohjoispuolella Sotkamossa (vyöhyke V/VI), Ruukissa (vyöhyke V) ja Rovaniemellä (vyöhyke VI/VII). Tavoitteenamme oli saada testattua mahdollisimman laaja lajikevalikoima ja kokeisiin saimme lajikkeet Aino, Alvar, Arto, Hele, North Blue, Patriot, Saani, Sine, Siro ja Tumma.

Kokeet olivat osa Marjanviljelystä vahva elinkeino Pohjois-Suomeen -hanketta, jota rahoitettiin Euroopan maaseuturahastosta Kainuun, Lapin ja Pohjois-Pohjanmaan Ely-keskusten kautta.

\begin{abstract}
Aineisto ja menetelmät
Pensasmustikan lajikekokeet perustettiin MTT Sotkamoon ja MTT Rovaniemelle vuosina 2008 ja 2009 sekä vuonna 2009 MTT Ruukkiin. Sotkamoon ja Rovaniemelle vuonna 2008 istutettiin lajikkeet Aino, Alvar, Arto, Jorma, North Blue ja Patriot ja vuonna 2009 Aino, Hele, Saani, Sine, Siro ja Tumma. Ruukkiin kaikki edellä mainitut lajikkeet istutettiin vuonna 2009 lukuun ottamatta lajikkeita Jorma ja Patriot, joiden taimia ei saatu. Vuonna 2008 taimet saatiin lahjoituksena Puutarha Tahvosilta ja vuonna 2009 taimet tuotettiin MTT Laukaassa. Vuonna 2008 istutetuissa taimissa oli istutettaessa mustikkasyöpää, mutta sitä ei enää istutuksen jälkeisinä vuosina havaittu.

Kokeita perustettiin ja hoidettiin vallitsevan viljelysuosituksen mukaisesti. Taimet istutettiin mustaan muovipenkkiin tiheyteen 5000 tainta/ha $2 \mathrm{~m}$ rivivälillä ja $1 \mathrm{~m}$ taimivälillä. Jokaista lajiketta istutettiin neljään lohkoon, viisi tainta jokaiseen ruutuun. Kokeet kasteltiin ja lannoitettiin tihkukastelulla. Kastelurajana -150 hPa ja lannoitteena Yara Ferticare 8-7-21. Kokeissa ei käytetty kemiallista kasvinsuojelua. Rikkakasvit kitkettiin käsin tarvittaessa.

Lajikkeista havainnoitiin talvivaurioiden määrää ja satotasoa. Talvivaurioiden määrä arvioitiin viisiportaisella asteikolla: $\mathrm{A}=$ ei talvivaurioita, $\mathrm{B}=$ vähäisiä vaurioita, $\mathrm{C}=$ keskinkertaisia vaurioita, $\mathrm{D}=$ pahoja vaurioita ja $\mathrm{E}=$ pääosin kuollut ensimmäisen talven jälkeen. Sadonkorjuut tehtiin koeruuduittain lajikkeiden kypsymisjärjestyksessä. Jokaisesta koeruudusta punnittiin koko sato ja laskettiin marjojen lukumäärä. Näiden tulosten perusteella laskettiin taimikohtainen keskisato ja keskimääräinen marjakoko.
\end{abstract}

\section{Tulokset ja tulosten tarkastelu}

Mikään testatuista lajikkeista ei pystynyt tuottamaan Rovaniemellä satoa. Yhtään testatuista pensasmustikkalajikkeista ei siis voida suositella Lappiin. Ruukissa ja Sotkamossa satoa poimittiin kaikista lajikkeista, vaikka heikoimmin menestyneillä lajikkeilla satotasot jäivät erittäin pieniksi. Millään lajikkeella satotasot eivät yltäneet Etelä-Suomessa saataviin satotasoihin. Parhaimmillaan 
satotasot olivat kokeissa 300-400 g/taimi eli 1500-2000 kg/ha (Taulukko 1), kun Etelä-Suomessa saadaan vuodessa satoa yleisesti $1-2 \mathrm{~kg} /$ pensas eli $5000-10000 \mathrm{~kg} / \mathrm{ha}$. Nykyisillä viljelyn tuotantokustannuksilla ja tuottajahinnoilla näissä kokeissa saadut satotasot eivät oletettavasti riitä kannattavaan kaupalliseen viljelyyn.

Näissä kokeissa parhaiten menestyneitä lajikkeita voi kuitenkin käyttää kotipuutarhalajikkeina EteläKainuussa ja eteläisellä Pohjois-Pohjanmaalla, jos hyväksyy alhaiset satotasot ja toistuvat talvivauriot. Tällaisia, edellä mainitulla alueella harrastajakäyttöön sopivia lajikkeita ovat ainakin Aino, Alvar, Jorma, Sine, Siro ja North Blue. Kaikkein talvenkestävimpiä näistä vaikuttaisivat olevan Aino ja Sine (Taulukko 2). Sadontuoton ja talvehtimisen kannalta heikoimpia lajikkeita Arto ja Patriot ei voida missään tapauksessa suositella Kainuuseen eikä Pohjois-Pohjanmaalle. Lajikkeista Saani, Hele ja Tumma ei vielä pystytä tämän koeaineiston perusteella antamaan luotettavia viljelysuosituksia.

Talvivaurioista huolimatta pensasmustikka kykeni sadontuottoon Kainuun ja PohjoisPohjanmaan eteläosissa. Etelä-Lapissa talvivauriot olivat liian voimakkaita ja kasvukausi oletettavasti liian lyhyt pensasmustikoiden menestymistä ajatellen.

Taulukko 1. Pensasmustikkalajikkeiden keskimääräinen satotaso (kg/ha, istutustiheys 5000 tainta/ha) Sotkamossa ja Ruukissa ryhmiteltynä istutus- ja sadonkorjuuvuosittain sekä kaikkien paikkakuntien satotuloksista laskettu keskimääräinen marjakoko. Rovaniemelle istutetut pensaat eivät tuottaneet satoa.

\begin{tabular}{|c|c|c|c|c|c|}
\hline & \multicolumn{2}{|c|}{ Sotkamo ist. 2008} & \multirow{2}{*}{$\begin{array}{l}\text { Sotkamo ist. } 2009 \\
\text { Sato } 2011\end{array}$} & \multirow{2}{*}{$\begin{array}{l}\text { Ruukki ist. } 2009 \\
\text { Sato } 2011\end{array}$} & \multirow{2}{*}{$\begin{array}{l}\text { Keskimääräinen } \\
\text { marjakoko }(\mathrm{g} / \mathrm{kpl})\end{array}$} \\
\hline & Sato 2010 & Sato 2011 & & & \\
\hline Aino & 405 & 1840 & 335 & 172 & 1,0 \\
\hline Alvar & 405 & 1124 & - & 449 & 1,0 \\
\hline Arto & 64 & 164 & - & 9 & 1,7 \\
\hline Hele & - & - & 151 & 265 & 0,3 \\
\hline Jorma & 146 & 1516 & - & - & 1,0 \\
\hline North Blue & 12 & 708 & - & 534 & 2,5 \\
\hline Patriot & 2 & 58 & - & - & 2,7 \\
\hline Saani & - & - & 121 & 102 & 0,7 \\
\hline Sine & - & - & 549 & 370 & 0,4 \\
\hline Siro & - & - & 971 & 1179 & 0,8 \\
\hline$\underline{\text { Tumma }}$ & - & - & 264 & 41 & 0,4 \\
\hline
\end{tabular}

Taulukko 2. Pensasmustikkalajikkeiden talvivauriot Rovaniemellä ja Sotkamossa vuosina 2009 - 2011 ja Ruukissa vuosina 2010 - 2011. Asteikko: A = ei talvivaurioita, B = vähäisiä vaurioita, $\mathrm{C}=$ keskinkertaisia vaurioita, $\mathrm{D}=$ pahoja vaurioita, $\mathrm{E}=$ pääosin kuollut ensimmäisen talven jälkeen.

\begin{tabular}{llll}
\hline & \multicolumn{3}{l}{ Talvehtiminen eri paikkakunnilla } \\
Lajike & Rovaniemi & Ruukki & Sotkamo \\
\hline Aino & D & C & C \\
Alvar & D & C & D \\
Arto & D & C & D \\
Hele & D & C & D \\
Jorma & D & - & D \\
North Blue & E & C & D \\
Patriot & E & - & D \\
Saani & D & C & D \\
Sine & D & C & C \\
Siro & D & C & D \\
Tumma & C & D & D \\
\hline
\end{tabular}




\section{Johtopäätökset}

Pensasmustikan kaupallinen viljely ei ole nykylajikkeilla kannattavaa Kainuussa, PohjoisPohjanmaalla tai Lapissa, koska satotasot jäävät alhaisiksi ja talvivauriot ovat toistuvia. Kainuun ja Pohjois-Pohjanmaan eteläosissa Pensasmustikka sopii kotipuutarhakasviksi, mutta Lapissa pensasmustikka ei menesty lainkaan.

Harrastajakäyttöön Kainuun ja Pohjois-Pohjanmaan eteläosia myöten sopivia lajikkeita ovat ainakin Aino, Alvar, Jorma, Sine, Siro ja North Blue. Kaikkein talvenkestävimpiä näistä vaikuttaisivat olevan Aino ja Sine. Sadontuoton ja talvehtimisen kannalta heikoimpia lajikkeita Arto ja Patriot ei voida suositella Kainuuseen eikä Pohjois-Pohjanmaalle. Lajikkeista Saani, Hele ja Tumma ei vielä pystytä tämän koeaineiston perusteella antamaan luotettavia viljelysuosituksia. 